\title{
Note on a Hoard of Iron Currency-Bars found on Worthy Down, Winchester
}

By Reginald W. Hooley, F.G.S.

[Read I7th February I921]

IN the year I9I9 it became necessary to excavate to a depth of $2 \mathrm{ft}$. over a given area on Worthy Down, near Winchester. At the north-east corner of the excavation a number of iron currencybars were uncovered. None of the excavators knew what they were at the time and they were thrown aside, but one of the party, Mr. C. H. Blenkinsop, eighteen months after, on visiting the British Museum, noticed similar objects labelled 'Iron Currencybars'. He returned to the site, collected several bars, and brought them to me. A few days afterwards I examined the ground in his company. The excavation was oblong, with its long axis east and west, and the section exposed showed 6 in. of soil and I ft. 6 in. of chalk. At the north-east angle was seen what appeared to be the section of one of the sides of a shallow trench filled with earth, chalk-rubble, and burnt flints. On digging to remove the turf on the surface contiguous to this section, the spade was checked by several iron currency-bars, which lay hidden by the grass that had grown over them since they were cast out. At $\mathrm{I} \mathrm{ft}$. 6 in. below the surface $\mathrm{I}$ found the end of a bar $8 \frac{3}{5}$ in. long, which fitted on to one of the bars already in my possession. The exact position and level of the original discovery were thus known. At a depth of $2 \mathrm{ft}$. the chalk was reached. The digging was then directed eastwards, and it was found that the soil deepened. A seam of flint 'pot-boilers' and charcoal was met with at $2 \mathrm{ft}$. $6 \mathrm{in}$. A fragment of a human cranium, bones and teeth of (?) horse, ox, pig, and sheep, with pieces of pottery were also found. These discoveries occurred on the I $3^{\text {th }}$ August 1920. Further excavations were made on various dates. At a depth of $3 \mathrm{ft}$. another layer. of burnt flints, mingled with bones of the same mammals, the skull of a small dog, and a portion of a triangular loom-weight were obtained. At this level the excavations were continuet, and the 
chalk was reached on the east side and observed to have a slope similar to that on the west. As the digging proceeded the chalk was exposed on every side, and it became evident that it was the rim of a pit. At a depth of $4 \mathrm{ft}$. bones, teeth, pieces of pottery, and burnt flints were discovered. At $5 \mathrm{ft}$. abundant burnt flints, fragments of pottery, a flint muller, bones, and teeth were met with, and subsequently the bottom of the pit was reached. A small piece of iron was found in the earth thrown out, and on the floor there were horn-cores and part of the frontal bone and the mandible of a sheep, bones of horse, ox, and pig. One ox femur exhibits cuts, and many split bones were observed, two of which had similar indentations. There were also fragments of pottery, and many burnt and smoked flints.

The floor of the pit was $6 \mathrm{ft}$. $8 \mathrm{in}$. below the surface. The pit was circular, with a diameter of $6 \mathrm{ft} .4$ in. ; the walls were vertical and the floor was at right angles to the walls and flat. The rim had a slope of $45^{\circ}$, was $3 \mathrm{ft}$. wide, and its inner edge was $3 \mathrm{ft}$. from the present surface. There were no steps in the chalk giving access to the pit, no hole in the floor for a post to carry a roof, nor any fireplace visible. No traces of smoke existed on the walls or floor, and the chalk was as clean as if freshly hewn. No tool marks were discernible.

The currency-bars were lying on the western rim of this pit. The remains of about thirteen were found, and of these seven are perfect, varying from $32 \frac{1}{2}$ in. to $34{ }_{10}^{7}$ in. in length. They are, as usual, flat, with squared edges. The extremity of the broader end is pinched in, so that the two edges in some cases meet in the median line, forming a sort of hollow handle. They taper in the other direction and terminate in a curved point. Judging by their weight, size, and the form of their handles, they belong to the double-unit denomination. In weight they vary from 553 grammes to 723 grammes. This lack of uniformity may to some extent be due to different degrees of waste from rust ; moreover, two of the bars have matter cemented to them by iron-rust, and another has a very small flint pebble in the hollow of its handle. The heaviest bar, which is $\mathrm{I} \frac{1}{5}$ in. longer than any of the others and seems to have suffered the least, does not agree with the standard weight of the double-unit denomination of currency-bars. Notwithstanding these facts, the average weight of the seven bars is $63 \mathrm{I} \cdot 7$ grammes, which approximates very closely to the $62.3 \cdot 7$ grammes or $22 \mathrm{oz}$, the presumed standard weight of the doubleunit. A portion of a currency-bar, which was broken by the spade, exhibits a clean, fresh fracture. It is remarkable that the interior appears to be quite unaltered, though there is a thin layer 
of rust outside. The transverse sections exposed have all the brilliancy of an iron bar just manufactured. The metal has a marked crystalline structure and, on breaking a fragment in

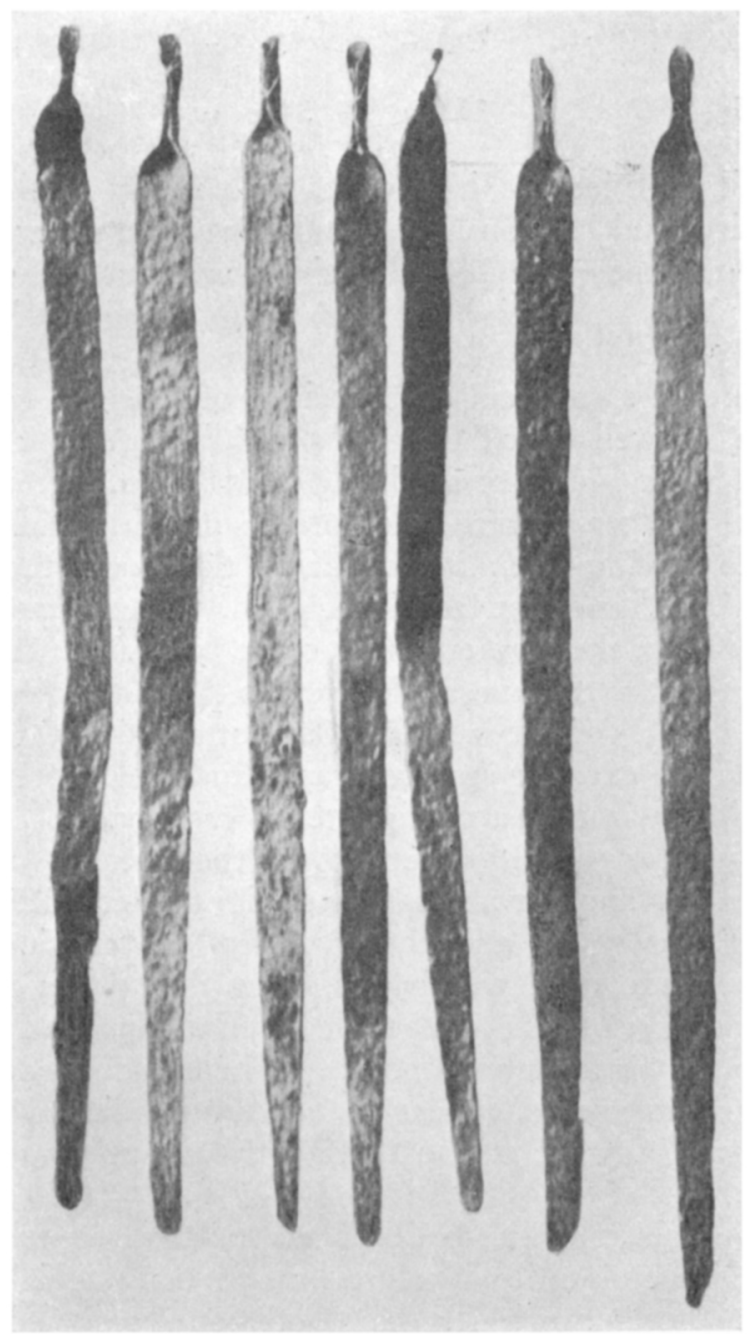

Currency-bars from Worthy Down, Winchester $\left(\frac{1}{7}\right)$.

a longitudinal direction, a similar structure and appearance were revealed. It is very tough, and strongly resists the action of the drill and the file. 


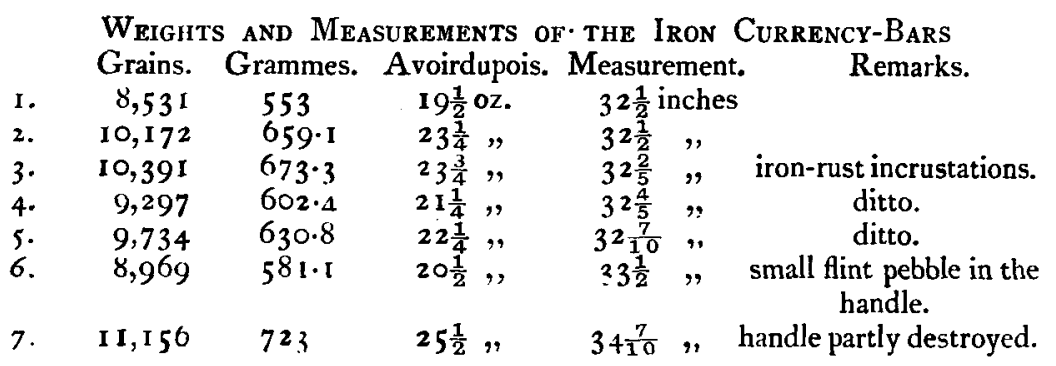

The small flat piece of iron which was found is thicker than a currency-bar, and has convex instead of vertical edges. It tapers slightly at one end, and has a straight edge at the other, with a width of $1 \frac{3}{8}$ in. Its weight is $2 \mathrm{oz}$. and its length 2 in.

All the pottery is hand-made. Three fragments, which fit together, formed a segment of the sides of a small, circular pot. It is made of well-baked clay of a reddish-brown colour; the paste is fine, with grains of sand and flint chips. It is straightsided and the outer surface is striated, some material, vegetable or otherwise, having been drawn down the vessel for trimming purposes. The inner surface is smooth. The circumference is ascertainable from the segment of its circle preserved, the diameter being 3 in. and the thickness of the sides $\frac{5}{16}$ of an inch.

About a quarter of the base of a flat-bottomed pot, with similar markings on the exterior surface, was found. An interesting fact about the latter is that a precipitate of carbonate of lime, apparently produced by heated water, covers the interior surface.

A segment of another and larger straight-sided pot proves that its diameter was $7 \frac{1}{2}$ in. and the thickness of the sides $\frac{5}{16}$ of an inch. It is made of a well-baked, very fine paste, mixed with a large proportion of sand, but with no flint particles. Both the inner and outer surfaces are smooth. The cooking-pots, of which the above are fragments, appear to be very similar to those from Oldbury Camp, figured in the Devizes Museum Catalogue, I 9 I I, pl. xviii, fig. $\mathbf{r}$.

There is a piece of well-baked black pottery, containing sand, mica, and a large quantity of white flint particles, which are much exposed on both the inner and outer surfaces, and give it a speckled appearance. The rim is very thick and slightly outturned to form an incipient beading, and the exterior surface is polished.

Another fragment is a well-baked piece of black clay, containing large and small grains of quartz and flint and mica particles. The exterior surface is smooth and has been subjected to bone polishing. Two small pieces of well-baked black clay appear to 
be covered on both surfaces with red slip. The remaining fragments need not be detailed, except to say that one of them is $\frac{5}{8}$ of an inch thick and of dark-coloured paste, with the outer surface burnt red. Both the exterior and interior surfaces are easily impressed by the finger nail. The portion of the triangular loomweight found is of burnt clay. It is pierced by an oblique hole. The flint muller possesses a square butt, well adapted to the hand, and the other end is rounded and much battered by use. Several fragments of tertiary sandstone, with one or more flat surfaces, were either portions of a quern or were used as whet-stones. Many small, rounded, tertiary flint pebbles with flat upper and lower surfaces were met with at all depths in the pit and may have been used as sling-stones.

Small fragments of soft, bright-red clay occurred throughout the pit. They readily leave a red track on being damped and drawn over an object and may have served the purposes of reddle.

Dr. C. W. Andrews of the British Museum (Natural History) kindly determined the mammalian remains. He reports in regard to the supposed horse teeth that they do not possess the characteristic enamel fold, but that this feature is sometimes absent in the horse. The skull of the dog belonged to an animal about the size of a terrier. It will be recalled that General Pitt-Rivers mentions that the size of the dogs found in the Romano-British villages of Woodcuts and Rotherly varied from the size of a mastiff to that of a terrier.

No Roman remains were found nor anything to suggest contact with Roman civilization. The site is on high ground about $330 \mathrm{ft}$. above O.D., with a gentle fall to the north, south, and east, and a rise to the west. No signs of other pits or depressions were visible, but by tapping the surface of the surrounding area, other pits were located and also a broad and long trench.

There are cultivation terraces to be observed within a mile of the pit. In the course of the excavations it was reported to me that half a mile to the eastward, when the foundations were being made for some buildings, many fragments of pottery were found. On hearing of this $I$ went over the ground where the excavated soil had been tipped and found pieces of grey, black, and buff wheel-turned ware, some of which had bead rims and others had cordons. In addition, I picked up fragments of Samian and New Forest ware, coarse hand-made pottery, and teeth of horse and sheep. Here we have undoubted Roman influence, but this pottery is of a much later date than the finds at the currency. bar site.

The objects discovered in the pit are similar to those found in 
some of the pit-dwellings of Wilts. The pottery seems to belong to the early La Tène period, and the evidence suggests that the pit and its contents belong to the Early Iron Age, and that the currencybars were the property of its owner. There were several pieces of daub found at different levels in the pit, from which we may conclude that it was probably roofed with timber, covered by wattle and daub. The earth which was placed under the eaves on the rim of the pit to keep out wind and rain would provide a good hiding-place for the valuable currency-bars in case of a sudden attack on the village, of which the pit formed a part.

The locality appears to be one which would well repay further systematic investigation, but it is a task too great for individual effort and I have no fund at my disposal to open up the site by hired labour.

The currency-bars and the other specimens will be permanently exhibited in the Winchester Museum.

\section{Discussion}

Mk. Reginald Smith recognized three sorts of pottery among the finds, the usual paste of the Early Iron Age being soft and brown with a soapy surface. There was also a thick and hard ware, brick-red in colour; and a large fragment almost black and particularly hard with a plain square lip. Those were presumably contemporary with the currency-bars which Caesar found in use at the time of his invasion. It was satisfactory to find a site uncontaminated by Roman relics; and the four currency-bars from Winchester in the British Museum, of the same denomination, might have come from Worthy Down. The loom-weight had been of the usual triangular form with the angles pierced, a type also found in Holland and Belgium.

Mr. BUSHE-Fox contended that some of the pottery resembled the earliest Hengistbury ware, of La Tène I period; and Mrs. Cunnington had found more of it at All Cannings Cross Farm, Wilts., ${ }^{1}$ in association with a brooch of La Tène I type. Thus the Winchester pit-dwelling had been in use for a long time: several layers were noticed in the filling, and he inquired at what level the pottery occurred.

MR. HoOLEY replied that the currency-bars were on the rim of the pit and the pottery occurred at all depths, so there was not necessarily any connexion between them.

The President said Mr. Dale was one of the most constant and industrious of the Society's local secretaries, and had most usefully introduced to the meeting the work done by $\mathrm{Mr}$. Heywood Sumner and Mr. Hooley. The former was not only an indefatigable searcher

I Wilts. Arch. Mag., xxxvii, 526. 
but had artistic powers which enabled him to illustrate with peculiar charm the accounts of his own discoveries. Till recent years Roman kilns had been practically unknown in Britain, and many that had come to light stood to Mr. Sumner's credit. The date of Mr. Hooley's pit-dwelling was uncertain, but some future discovery might show how long before Caesar currency-bars were in use. Meanwhile the curator at Winchester would continue the arrangement and improvement of his museum, which under his charge had become a credit to the county. To Mr. Dale was due the presentation of an interesting report on archaeological progress in Hants. 